Originalni naučni rad

UDK: $355.244 .2: 519.876 .5$

Primljen: 28. 8. 2015.

351.862.22:004.942

Prihvaćen: 29. 6. 2016.

doi:10.5937/nbp1602035J

\title{
SIMULATION OF EVACUATION SITUATIONS IN ORDER TO PROTECT HUMAN LIVES AND MATERIAL PROPERTY
}

\author{
Radoje Jevtić ${ }^{1}$ \\ Electrotechnical School "Nikola Tesla", Niš
}

\begin{abstract}
Summary: The term 'evacuation' presents rather a wide concept, but generally it presents the safest, fastest and shortest way of getting out from endangered objects, situations or places for people, animals and material property to a secure place. The reasons for evacuation could be different: fire, gas, chemicals, war situations, bomb threats, terrorist attack, earthquakes, overflows, hurricanes, industrial accidents, nuclear accidents, eruptions of volcanoes, tsunamis, civil disorders, etc. Every evacuation situation is very complex and could have a very unpredictable development because it depends on many different parameters often hard to be controlled. So, it is very important to predict somehow, as much as possible, potential evacuation scenarios. One of the very good, economic and safe ways is to use the Pathfinder simulation software. This paper has been written to show the prediction of the evacuation situations development and meaning of simulation software usage in order to protect human lives and material property.
\end{abstract}

Keywords: evacuation, safety, simulation.

$1 \mathrm{PhD}$ in technical science; milan.jvtc@gmail.com 


\section{Introduction}

The term 'evacuation' dates before the XIII century, when it mostly presented a military term for army retreat from battlefield. Latter, in the XVIII century, this term started being applied in a wider sense, as it is used today. Evacuation, in one sense, means planed, organized and temporary relocation of people, animals, material and cultural property, state organs and other legal forms from an endangered territory to a safe territory, determined by protection plan in special situations. In etymological sense, the word 'evacuation' is not complicated and has a similar meaning to scientific term for vacuum, empty space without any parts or elements. The words 'vacuum' and 'evacuation' originate from Latin adjective vacuus - empty, neuter gender, vacuum. The term 'evacuation' in medicine means transport of vulnerable or ill people from one location to another. In military sense, this term means leaving from some operative area, where population, hospital, military and other storages, etc. leave this area.

The reasons for evacuation, as it was noted, could be different and very complex: fire, gas, chemicals, war situations, bomb threats, terrorist attack, earthquakes, overflows, hurricanes, industrial accidents, nuclear accidents, eruptions of volcanoes, tsunamis, civil disorders, etc. It could be seen that for different evacuation situations different structures could be engaged: fire brigades, police, military, civil protection or, very often, some of their synchronized combinations. There are many reasons why fire brigades and police particularly must somehow be in situation to, as much as possible, predict possible developments of a crisis situation, and according to that realize the evacuation successfully. ${ }^{2}$

One of the very complex cases in the evacuation issues is evacuation of objects with great number of humans inside in case of fire. These objects could be different buildings, schools, markets, shopping centres, hospitals, theatres and similar objects. Fire presents a very unpredictable accident and could cause huge damage to human lives and material property. This is the fact that significantly can complicate projecting and design of evacuation routes and, if they are not realized correctly directly harm safety of humans inside them. There were many examples that could confirm these facts: September 11 in New York, Chernobyl disaster, Fukushima nuclear disaster, the Torch building in Dubai, etc. Only in America in 2010, over 1800 fires in residential buildings were reported, where there were 2635 cases of death, 725 cases of injuries and over 196 millions of dollars of loss. ${ }^{3}$

2 R. Jevtić, Simulation of the shopping centre "Zona I" evacuation, Tehnika elektrotehnika, number 3/2014, Beograd, pp. 537-541.

3 NFA, Fatal fires in residential buildings, Topical fire report series, Vol 11, 2010, USA, pp. 3-11.

[36] NBP • Žurnal za kriminalistiku i pravo 
Very important task in every evacuation strategy and every evacuation plan is the projecting of possible evacuation routes. Evacuation routes were projected as primary and secondary. Primary evacuation route is most frequently a route for normal communication in an object. For example, these routes could be stairs, hallways, corridors and other surfaces used for communication in an object or on a separate floor. They are with different dimensions for every type of object. These routes are the routes that fire services use in case of fire. The secondary routes depend on objects' purpose. These routes could involve windows, roofs, etc. Both types of evacuation routes must satisfy many standard and non-standard requirements according to the number of people, type and purpose of object, speed of people moving, necessary time of evacuation, etc. The evacuation routes must be clearly visible at the evacuation plan.

There are many unpredictable parameters that could have a very big influence on evacuation. One particularly interested aspect according to object or location evacuation is panic and stress that affect the occupants. It is known that calm occupants have bigger chances to leave the determinate object or location than the occupants influenced by stress and panic. In panic and stress situations, occupants move faster but in a chaotic way, for example, in terrorist attack situation. ${ }^{4}$ That implies many unexpected situations in an object or at a location. Evacuation routes in objects have their own maximal occupants' flow. That is especially important for stairs, elevators, hallways, corridors, etc. It is very often the case that in the state of panic and stress occupants shrilly try to get out from the object or try to leave the location and cause tragedy. There were lots of similar cases with tragic epilogue. The occupants' behaviour, knowledge and education, physical and psychic condition (occupant speed, panic and stress influence, moral and human qualities) should be studied in details. It is also important to note that the state of panic of occupants is pretty much determinate than the state that implies fast moved occupants. ${ }^{5}$

The successful object evacuation and saving of human lives and material property can be significantly improved in early stage of disaster, for example in early stage of fire or in early stage of overflow. That implies using of different modern monitoring types, sensors, information technologies, connection instruments and other necessary things that were defined by proper standards and laws. Very important fact for successful evacuation is that disaster should be discovered in its early stages. This is especially important for object evacuation in case of fire. All these exposed facts show that the object evacuation must be realized on proper laws and standards regulated regardless of its financial aspect. Of course, one of the best ways for decreasing of human deaths

4 R. Gaćinović, Oblici savremenog terorizma, NBP - Journal of Criminalistics and Law, vol. XVII, number 1/2012, Beograd, pp. 1-18.

5 R. Jevtić, M. Blagojević, Simulation of the school object evacuation, Tehnika elektrotehnika, number 2/2013, Beograd, pp. 365-370. 
and material loss is usage of simulation software for evacuation. ${ }^{6}$ Usage of such software could, in a safe and economic way for humans and material property, significantly predict potential evacuation scenarios and determine the best way of their solutions.

\section{Pathfinder Simulation Program}

The successful evacuation of an object and saving of human lives and material property can be significantly improved with the usage of simulation programs, such as Pathfinder. Pathfinder is an agent based egress and human movement simulator. There are several different versions of this program. Pathfinder provides a graphical user interface for simulation design and execution as well as $2 \mathrm{D}$ and $3 \mathrm{D}$ visualization tools for results analysis. The movement environment is a 3D triangulated mesh designed to match the real dimensions of a building model. This movement mesh can be entered manually or automatically based on imported data (e.g. FDS geometry). Walls and other impassable areas are represented as gaps in the navigation mesh. These objects are not actually passed along to the simulator, but are represented implicitly because occupants cannot move in places where no navigation mesh has been created. Doors are represented as special navigation mesh edges. Every door has its own length. In all simulations, doors provide a mechanism for joining rooms and tracking occupant flow. Depending on the specific selection of simulation options, doors may also be used to explicitly control occupant flow. Stairways are also represented as special navigation mesh edges and triangles. Occupant movement speed is reduced to a factor of their level travel speed based on the incline of the stairway. Occupant speed could be defined for different evacuation scenarios. ${ }^{7}$ Each stairway implicitly defines two doors. These doors function just like any other door in the simulator but are controlled via the stairway editor in the user interface to ensure that no geometric errors result from a mismatch between stairways and the connecting doors.

Occupants are modelled as upright cylinders on the movement mesh and travel using an agent-based technique called inverse steering. Each occupant calculates movements independently and can be given a unique set of parameters (maximum speed, exit choice, 3D model, etc). The example of occupant's movement in particular object is presented in Figure 1.

6 R. Jevtić, The simulation of sanitary objects evacuation-an example of hotel Radon in Niška Banja, Tehnika elektrotehnika, number 3/2015, Beograd, pp. 545-550.

7 R. Jevtić, Evacuation from tunnels: An example of Straževica tunnel, Vojnotehnički glasnik, Vol 64, number 3/2016, Beograd, pp. 754-768. 


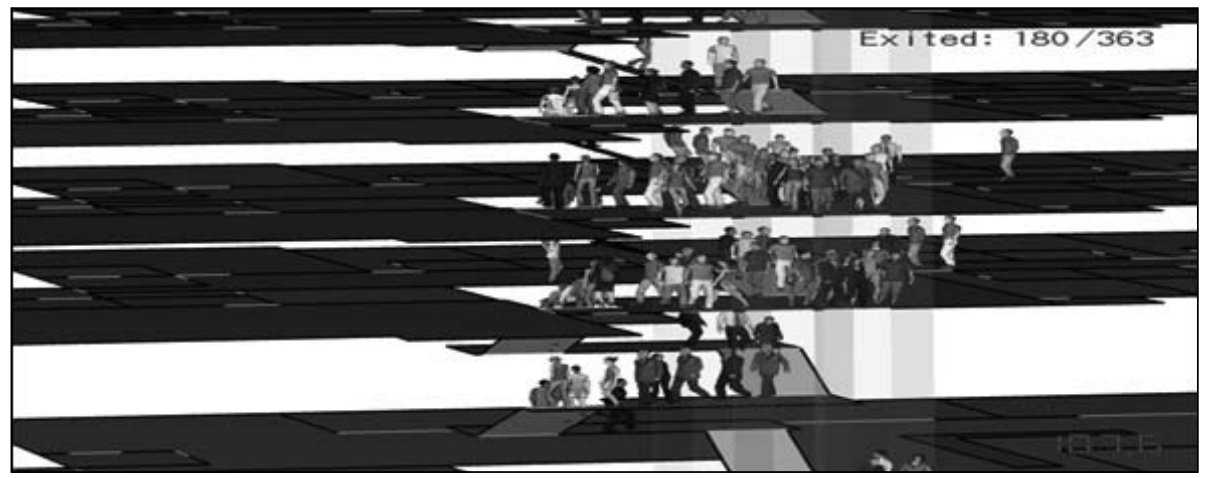

Figure 1. Modelled occupants presented in the Pathfinder's simulation model

Pathfinder supports two movement simulation modes. In "Steering" mode, doors do not act to limit the flow of occupants; instead, occupants use the steering system to maintain a reasonable separation distance. In SFPE mode, occupants make no attempt to avoid one another and are allowed to interpenetrate, but doors impose a flow limit and velocity is controlled by density. Simulator users can freely switch between the two modes within the Pathfinder user interface and compare answers. ${ }^{8}$

One particularly appropriate software possibility is importing files created in 3D CAD, FDS and PyroSim. These files have their own geometry which can be used in Pathfinder and significantly save time needed to complete the whole evacuation and fire project. The imported geometry is sent as-is to 3D Results, resulting in a clean and fast graphical representation of the data. The used version of Pathfinder for noted paper results was 2012 version.

\section{Simulation model}

The simulation model in Pathfinder should be created in real dimensions. This model also could be imported from some other program with some modifications (AutoCad, for example). In this paper, three different objects and theirs Pathfinder presentations will be presented: Electrotechnical School "Nikola Tesla" in Niš, "Zona I" Shopping Centre in Niš and Radon Hotel in Niška Banja.

Electrotechnical School "Nikola Tesla" in Niš is the secondary vocational school with more than 800 pupils and more than 100 employees. The school building is huge and it consists of laboratory part, classrooms part with offices, 8 Thunderhead, Pathfinder Example Guide, 2012, USA. 
toilets, the library and the gymnasium. Approximate building ground surface is about 2,542.91 square metres. Object has three floors with maximal height about $12 \mathrm{~m}$. The laboratory part of the Electrotechnical School "Nikola Tesla" has also three floors and ground surface about $708.05 \mathrm{~m}^{2}(40.46 \mathrm{~m} \mathrm{x} 17.5 \mathrm{~m}) .{ }^{9}$ At the first floor of the laboratory part there are several laboratories, stuff office, the carpenter room, the canteen, pupils' club and refrigerate devices room. The second and the third floors have only laboratories. Electrotechnical School "Nikola Tesla" in Niš and its appropriate Pathfinder presentation are presented in Figure $2(a, b){ }^{10}$
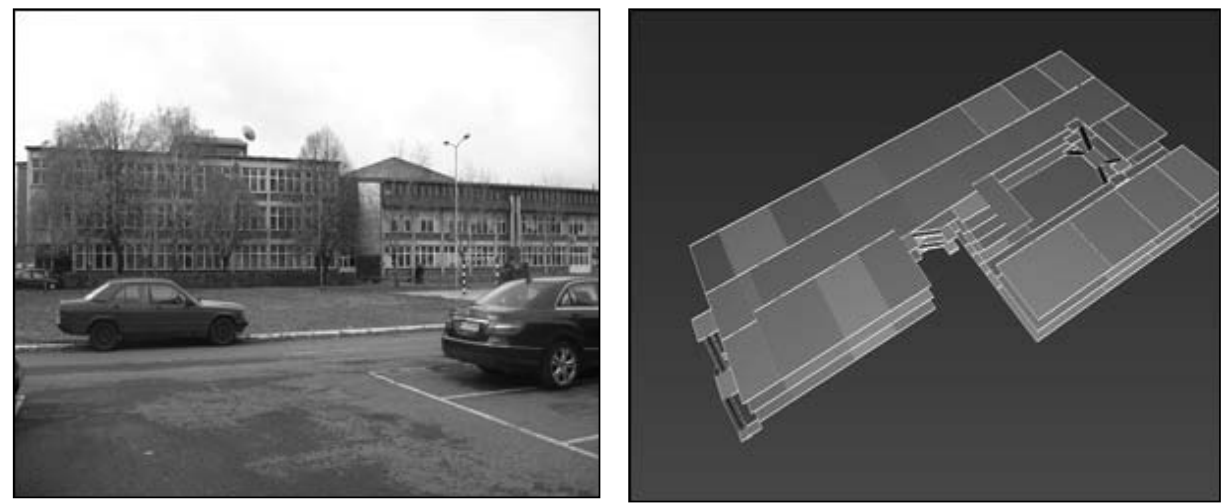

Figure 2. Electrotechnical School "Nikola Tesla" in Niš (a) and its Pathinder presentation (b)

"Zona I" Shopping Centre in Niš is the object with the approximate size of $56 \mathrm{~m} \mathrm{x} 20.5 \mathrm{~m}$. It is located in No. 67 Bulevar Nemanjića Street. It was built with the idea to provide all types of stuff so that there were no needs for living in the downtown. This shopping centre is one of three shopping centres that were built in the Bulevar Nemanjića Street. They are located at only few hundred meters distance between them. There are lot of rooms with different purposes in the object: shops, markets, bank, pharmacies, cafes, etc. It has basement and two floors with four exits/inputs, two from the front and two from the back side of the object. The width of stairs was $1.28 \mathrm{~m}$. The width of the exit/input doors was $1.82 \mathrm{~m}$. There was a lift in the object, but this lift was cargo lift and it was irrelevant for evacuation. The pictures of "Zona I" Shopping Centre in Niš and its inside details from the first floor are presented in Figure 3(a,b). ${ }^{11}$

9 R. Jevtić, The influence of air flow speed on fire propagation in object, Arhitektura i urbanizam, Vol 40, Beograd, pp. 59-65.

10 R. Jevtić, M. Blagojević, Simulation of the school object evacuation, Tehnika elektrotehnika, number 2/2013, Beograd, pp. 365-370.

11 R. Jevtić, Simulation of the shopping centre "Zona I" evacuation, Tehnika elektrotehni$k a$, number 3/2014, Beograd, pp. 537-541. 

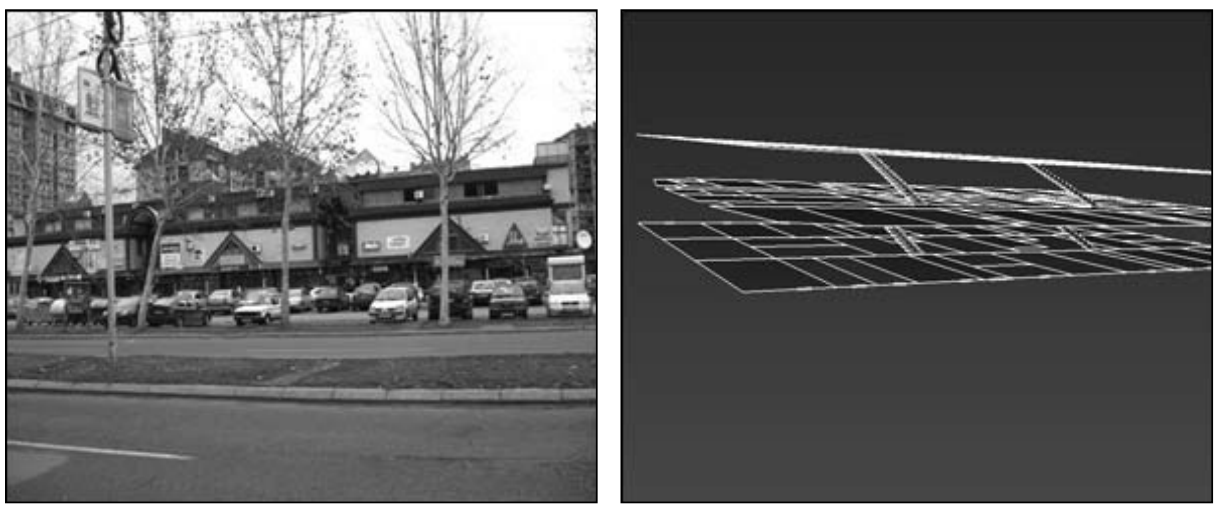

Figure 3. "Zona I" Shopping Centre in Niš (a) and its Pathfinder presentation

Radon Hotel is one of the three hotels that belong to the Institute of Niška Banja. Each of these hotels is a unique complex that possesses accommodation capacities, complete therapy blocks (hydro, electro, kinesiotherapy and mud therapy), several halls for individual or group therapy, recreation and fun. Radon Hotel is located about 100 meters far from the promenade in Niška Banja. It is a high building with basement and 11 floors. Radon Hotel has capacity of 300 beds, commodious rooms, apartments and luxury apartments, amphitheatre with 300 seats, plenum hall with 60 seats, the hall for VIP guests, the restaurant with 300 seats, café restaurant, bar, summer garden, swimming pool with thermal water, wellness centre and parking at the back side. The arrangement in Radon Hotel was formed according to the condition and possibilities of patients. For example, at the basement there are swimming pool, wellness centre and reception part. At the first floor, there are baths, ambulances, amphitheatre and similar rooms. At the second floor, there are store room, offices, waiting rooms and rooms for patients. At the third floor, there were kitchens, restaurant, small hall, X-ray rooms, laboratory and offices. At the fourth floor, there are also the reception, the library, several stores, café and several exits to the large terrace with a great view. The fifth floor includes the rooms for patients, offices, intensive and semi-intensive care and similar rooms. The sixth, seventh, eighth, ninth, tenth and eleventh floors mostly contain the rooms for patients. The patients were disposed according to their health condition and level of illness. Radon Hotel has three lifts for patients and personnel and one cargo lift. One lift has capacity of 10 persons while other two have capacity of 8 persons respectively. In the hotel, there are the main stairs and the secondary stairs. Hotel surrounding includes a beautiful park. Radon Hotel in Niška Banja is presented in Figure 4 (a, b). ${ }^{12}$

12 R. Jevtić, The simulation of sanitary objects evacuation-an example of hotel Radon in Niška Banja, Tehnika elektrotehnika, number 3/2015, Beograd, pp. 545-550. 

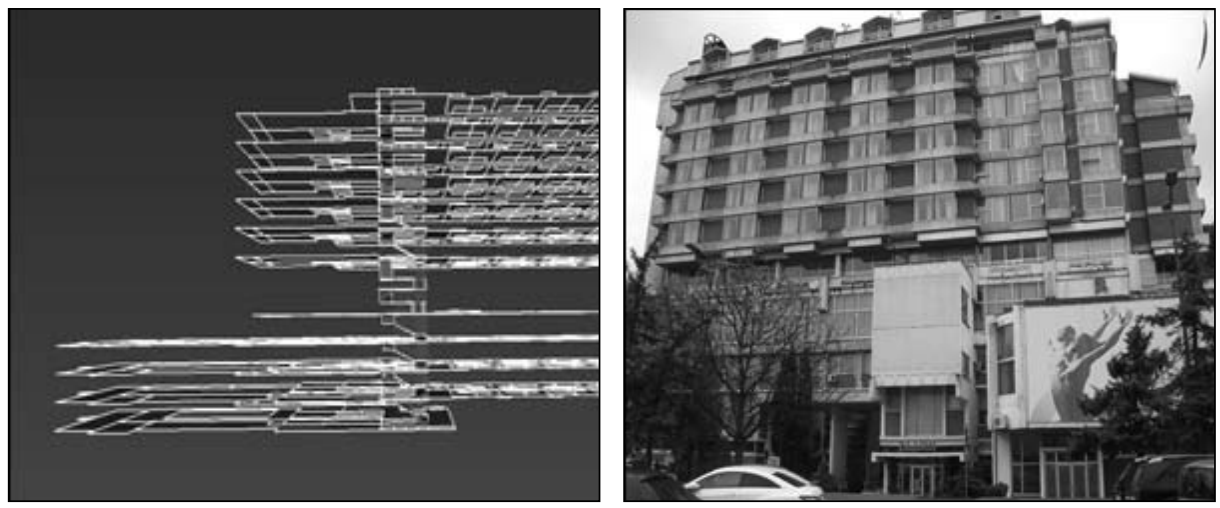

Figure 4. Radon Hotel in Niška Banja, back side (a) and its Pathfinder presentation (b)

After object's model construction, Pathfinder enables creation of different scenarios, which means different occupant's position, different occupant's speed, different occupant's movement, stairs and elevators positioning, elevators capacity and speed, jamming possibilities, exits positions and lot of other factors and parameters that have great importance for evacuation. Properly created simulation model could also check the existing primary and secondary evacuation routes in sense of evacuation speed and also find new safe and economic ways for evacuation.

\section{Simulation and simulation results}

The simulation duration depends on simulation model in Pathfinder complexity. After the end of the simulations, different results are provided. The results are presented in the form of a diagram. An example of simulation moments in Pathfinder, the simulation moments from "Zona I" Shopping Centre in Niš evacuation and from Radon Hotel in Niška Banja evacuation are presented in Figure $5(a, b)$. 


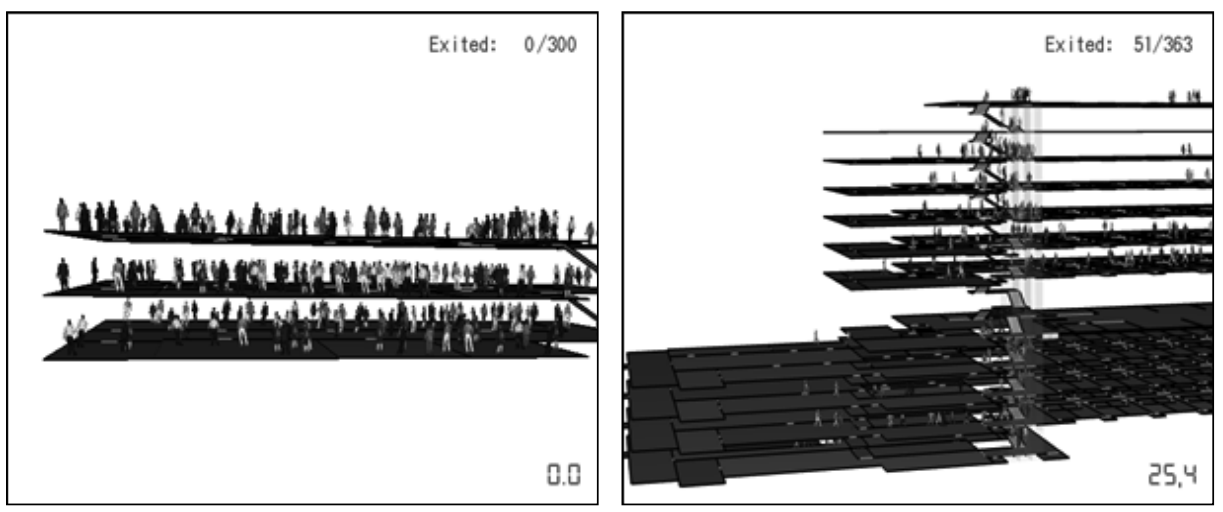

Figure 5. Simulation moments from "Zona I" Shopping Centre in Niš evacuation (a) and from Radon Hotel in Niška Banja evacuation (b)

The importance of different scenarios simulation in one simulation model is of the crucial meaning for saving human lives. As the first example different speeds of occupants in the Electro technical school "Nikola Tesla" in Niš could be used. The scenario has included that fire started at the laboratory part of the school and that fire started at the classrooms part on the second floor of the school. The results are presented in Figure 6.

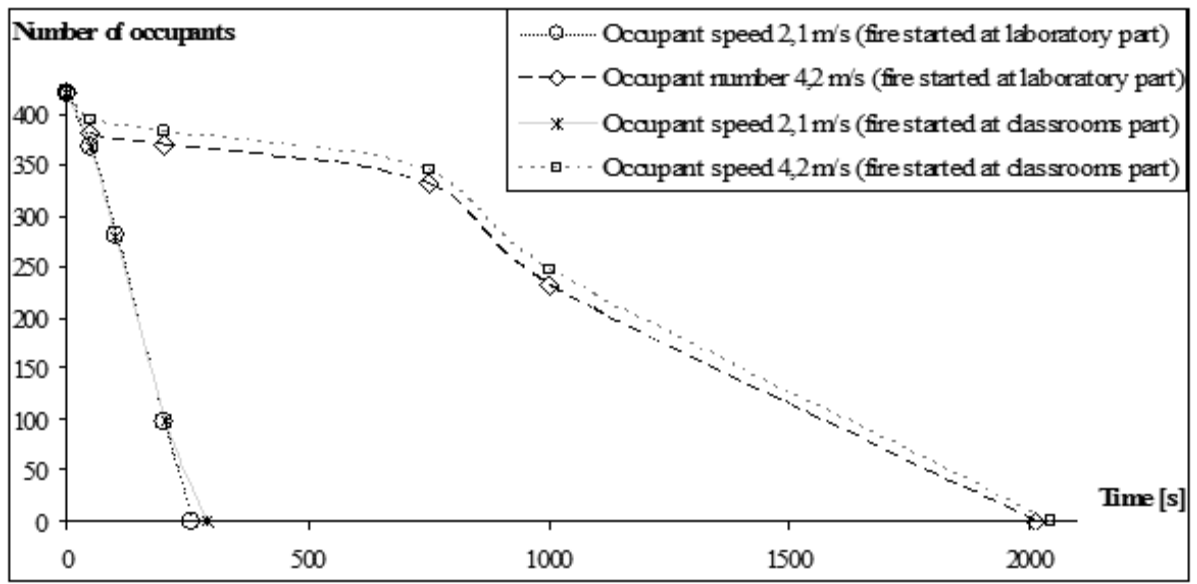

Figure 6. Simulation results for scenarios when fire started from the laboratory part and when the fire started at classrooms part on the second floor

The simulation results showed that for occupant speed of $2.1 \mathrm{~m} / \mathrm{s}$, the maximal evacuation time did not pass 500 seconds and occupants were not stuck. As it could be seen in Figure 6, the evacuation times for occupant speed of 2.1 
$\mathrm{m} / \mathrm{s}$ were, when the fire had started at the laboratory part or the classrooms part, 263 seconds and 298 seconds respectively, depending on where the fire started. The bigger difference between occupant speed of $2.1 \mathrm{~m} / \mathrm{s}$ and $4.2 \mathrm{~m} / \mathrm{s}$ showed that occupants would be stuck for the occupant speed of $4.2 \mathrm{~m} / \mathrm{s}$. The complete number of occupants was 420 , randomly positioned. This stuck was a consequence of limited pass flow (for example stairs flow or exit doors flow). Taking into account the fact that under fire and fire consequences (flame and smoke particularly) occupants flow and moving through flow spots became more difficult and result in increased time needed for object evacuation. ${ }^{13}$

As the second example different speeds of occupants in "Zona I" Shopping Centre in Niš could be used. The results are presented in Figure 7.

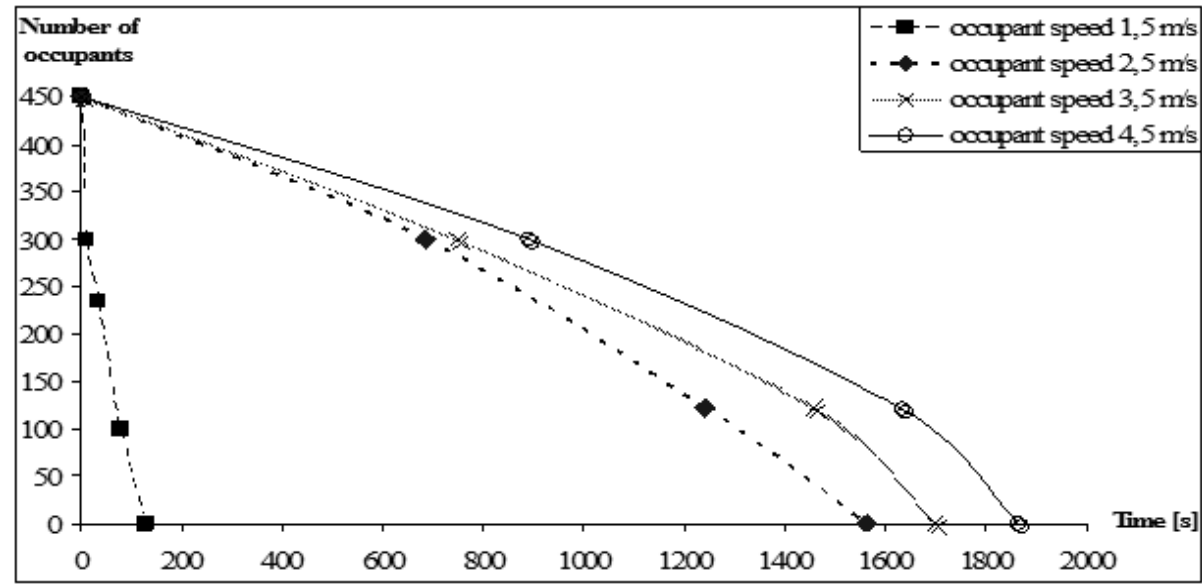

Figure 7. Simulation results for different speeds of 150 occupants per floor in "Zona I" Shopping Centre in Niš

The simulation results showed for 150 occupants per floor randomly positioned that the minimal times for occupant speeds from $2.5 \mathrm{~m} / \mathrm{s}$ to $4.5 \mathrm{~m} / \mathrm{s}$ were from 1560 to almost 1900 seconds, which was pointed to the stuck situation and, as it was shown, it took a lot of time to resolve the stuck situation. It is very important to note that these situations could be very unpredictable according to time needed to resolve and the consequences that could arise. But, for example, according to the data in the last years, "Zona I" Shopping Centre, for the most of the time was half empty, which considered mostly the people who worked in the shops, which is appropriate to the fact that less occupants could move faster without stuck possibilities. Of course, it is important to know and to predict the possible situations with more occupants in the object.

13 R. Jevtić and J. Ničković, Object evacuation for different speeds of occupants, $58^{\text {th }}$ ETRAN Conference, 2014, Vrnjačka Banja. 
As the third example different scenarios could be used in Radon Hotel in Niška Banja. The simulation of hotel occupants' evacuation was realized for three scenarios. The reason for that was in fact that different types of patients do not have the same movement speed, according to the degree of their illness conditions. The first scenario considered that occupants on the fifth and sixth floors had speed of $0.15 \mathrm{~m} / \mathrm{s}$ and needed help in evacuation. The other occupants from all of the other floors had speed of $1 \mathrm{~m} / \mathrm{s}$. The second scenario considered that occupants on the fifth and sixth floors had speed of $0.15 \mathrm{~m} / \mathrm{s}$ and needed help in evacuation, while other occupants had speed of $0.75 \mathrm{~m} / \mathrm{s}$. The third scenario considered that occupants on the fifth and sixth floors had speed of $0.15 \mathrm{~m} / \mathrm{s}$ and needed help in evacuation, while other occupants had speed of $0.6 \mathrm{~m} / \mathrm{s}$. The simulation results are presented in Figure 8 .

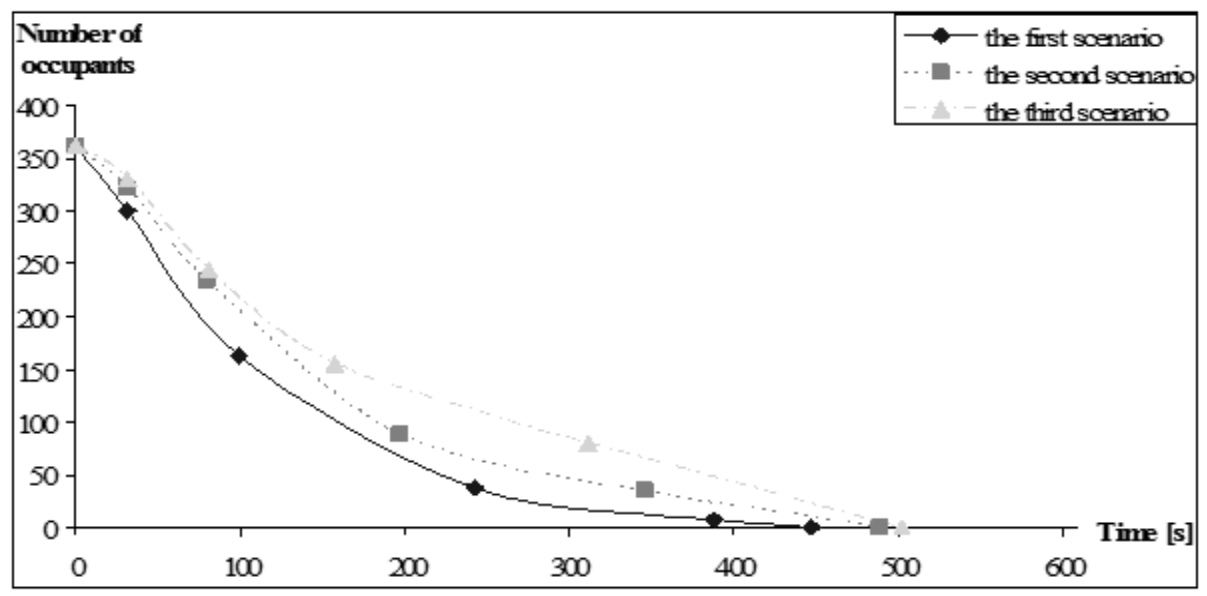

Figure 8. Simulation results for different scenarios from Radon Hotel in Niška Banja

\section{Discussion}

The noted examples show the great importance of evacuation prediction and how the evacuation problem could be complicated related to different parameters. The first and the second example showed that even with the good projection of possible evacuation routes, if the speeds of occupants were over determinate value, stuck situations were inevitable. The higher occupants' speeds often presume panic and stress present which leads to very unpredictable, chaotic and complex situations that could finish, very often, with death. In case of fire, stuck, panic and stress could be very dangerous for the right 
time evacuation because fire and combustion products have a great influence on occupants in short time. For example, carbon monoxide, carbon dioxide, flame and other combustion products could harm human lives in very short time interval. ${ }^{14}$ For example, situation with bomb threat, where the police forces and fire brigades must react in a synchronized way could be very difficult for this type of objects. At the same time, the possibilities for police and fire brigades on the one hand, and fast and safe occupant evacuation on the other hand, must be provided. The situation with an earthquake could also be complicated and problematic. ${ }^{15}$

The third example showed the evacuation of one very special object. The occupants of this object are mostly move slowly or are immobile, which is an important fact for evacuation. Although the object contains three passenger elevators the occupant evacuation could be significantly onerous. Many different services must take part in the evacuation of such an object. ${ }^{16}$

\section{Conclusion}

Noted examples showed both generally and particularly how the evacuation of the objects with lot of people inside could be serious and complex task for human and material protection. It is almost impossible to control all of parameters that evacuation depends on. This is why the potential prediction of evacuation and creation of potential evacuation scenarios with proper software present very effective, safe and economic way of evacuation prediction. This software could also check the exiting evacuation routes, find new potential routes and calculate complete time needed for evacuation.

Terrorism currently presents very difficult and unpredictable problem. ${ }^{17}$ The stopping and effective prediction of all potential consequences of terrorism significantly improve human and material property safety. The right time and safe evacuation presents, of course, great part in solving of this problem, especially in objects with lot of people inside. ${ }^{18}$

This paper has been written to show the importance in prediction of evacuation and evacuation scenarios in order to preserve human lives and material property.

$14 \mathrm{R}$. Jevtić, Combustion as fire consequence-great danger for humans health, Zdravstvena zaštita, number 9/2015, Beograd, pp. 55-62.

15 R. Jevtić, Fire simulation in house conditions, Tehnika elektrotehnika, number 1/2016, Beograd, pp. 160-166.

16 R. Jevtić, The importance of fire simulation in fire prediction, Tehnika Elektrotehnika, number 1/2014, Beograd, pp. 153-158.

17 D. Živaljević and A. Jugović, Terrorism as security problem and social deviance, NBP Journal of Criminalistics and Law, vol. XIX, number 1/2014, Beograd, pp. 85-96.

18 R. Jevtić and J. Ničković, Simulation of residential object evacuation, 57 ${ }^{\text {th }}$ ETRAN Conference, 2013, Zlatibor.

[46] NBP • Žurnal za kriminalistiku i pravo 
The successful prediction could be used with proper simulation software, such as Pathfinder (version 2012 in this paper). This and similar software should and must present obligatory engineer's tool in order to solve this kind of problems.

\section{References}

1. Gaćinović, R; Oblici savremenog terorizma, NBP - Journal of Criminalistics and Law, vol. XVII, number 1/2012, Beograd.

2. Jevtić, R and Ničković, J; Object evacuation for different speeds of occupants, $58^{\text {th }}$ ETRAN Conference, Vrnjačka Banja, 2014.

3. Jevtić, $\mathrm{R}$ and Ničković, J; Simulation of residential object evacuation, $57^{\text {th }}$ ETRAN Conference, Zlatibor, 2013.

4. Jevtić, R, Blagojević, M; Simulation of the school object evacuation, Tehnika elektrotehnika, number 2/2013, Beograd.

5. Jevtić, R; Combustion as fire consequence-great danger for human health, Zdravstvena zaštita, number 9/2015, Beograd.

6. Jevtić, R; Evacuation from tunnels: An example of Straževica tunnel, Vojnotehnički glasnik, Vol 64, number 3/2016, Beograd.

7. Jevtić, R; Fire simulation in house conditions, Tehnika Elektrotehnika, number $1 / 2016$, Beograd.

8. Jevtić, R; Heat detectors-Division, Positioning in Object and Simulation, Tehnika Elektrotehnika, number 2/2015, Beograd.

9. Jevtić, R; Simulation of the shopping centre "Zona I" evacuation, Tehnika Elektrotehnika, number 3/2014, Beograd.

10. Jevtić, R; The importance of fire simulation in fire prediction, Tehnika Elektrotehnika, number 1/2014, Beograd.

11. Jevtić, R; The influence of air flow speed on fire propagation in object, $A r$ hitektura i urbanizam, Vol 40/2016, Beograd.

12. Jevtić, R; The simulation of sanitary objects evacuation-an example of hotel Radon in Niška Banja, Tehnika elektrotehnika, number 3/2015, Beograd.

13. NFA; Fatal fires in residential buildings, Topical fire report series, Vol 11, USA, 2010.

14. Thunderhead, Pathfinder Example Guide, USA, 2012.

15. Živaljević, D and Jugović, A; Terrorism as security problem and social deviance, NBP - Journal of Criminalistics and Law, vol. XIX, number 1/2014, Beograd. 


\title{
SIMULACIJE EVAKUACIONIH SITUACIJA U CILJU ZAŠTITE LJUDSKIH ŽIVOTA I MATERIJALNIH DOBARA
}

\author{
Radoje Jevtić \\ Elektrotehnička škola „Nikola Tesla“, Niš
}

Sažetak: Cilj autora u ovom radu bio je da pokaže mogućnosti predviđanja razvoja evakuacionih situacija i značenje upotrebe simulacionog softvera u cilju zaštite i spasavanja ljudskih života i materijalnih dobara. Realizacija evakuacije može biti veoma komplikovana, jer zavisi od ogromnog broja faktora, od kojih je neke veoma teško predvideti. Samim tim, rizik po ljudske živote i materijalna dobra postaje veći. To se pogotovu odnosi na objekte u kojima se, zbog prirode njihove namene, nalazi veći broj ljudi, staraca, dece i osoba sa raznim vrstama invaliditeta. Zbog toga je veoma važno predvideti što veći broj evakuacionih scenarija i na osnovu njih predvideti odgovarajuće evakuacione tehnike pomoću kojih se na najbezbedniji način za ljude i materijalna sredstva realizuje sama evakuacija. Da bi se to uradilo na maksimalno efikasan i bezbedan način, neophodno je korišćenje odgovarajućeg softvera za simulaciju evakuacije. Mogućnosti i koristi od upotrebe takvog softvera su velike. Za realizaciju evakuacionih scenarija u ovom radu korišćen je softver Pathfinder 2012. Rezultati koji su navedeni u radu pokazali su da se pomoću ovakvog softvera može odrediti minimalno vreme evakuacije, vreme evakuacije ukoliko se koriste razne evakuacione rute, vremena evakuacija za različite brzine kretanja osoba koje se nalaze u određenom objektu, kao i efekti panike koji se predstavljaju preko znatno dužeg vremena potrebnog za evakuaciju određenog objekta. Simulirani objekti su poslužili i u mnogim drugim istraživanjima i testovima vezanim za mogućnosti evakuacije sa različitim evakuacionim scenarijima, a takođe mogu poslužiti i u simulaciji požara koja se može realizovati u drugom simulacionom softveru. Autor je u ovom radu pokazao da simulacioni softver mora biti važan i obavezan deo inženjerskog alata u cilju efikasnog, bezbednog i jeftinog rešavanja problema vezanih za evakuaciju kao meru zaštite i spasavanja.

Ključne reči: evakuacija, bezbednost, simulacija. 